Eur. J. Clin. Chem. Clin. Biochem.

Vol. 32, 1994, pp. 19-25

(C) 1994 Walter de Gruyter \& Co.

Berlin - New York

\title{
Efficacy of Transferrin Determination in Human Sera in the Diagnosis of Iron Deficiency
}

\author{
By W. Withold, Christine Neumayer, R. Beyrau, M. Heins, S. Schauseil and W. Rick \\ Institut für Klinische Chemie und Laboratoriumsdiagnostik, Medizinische Einrichtungen der \\ Heinrich-Heine-Universität Düsseldorf, Germany
}

(Received June 17/September 9, 1993)

Summary: Apparently healthy persons $(n=425)$ as well as 264 patients characterized by an iron concentration in serum $<7.2 \mu \mathrm{mol} / 1$ were examined. A latent iron deficiency was defined as a concentration of ferritin $<20 \mu \mathrm{g} / \mathrm{l}$ (males) and $<15 \mu \mathrm{g} / \mathrm{l}$ (females), without anaemia; manifest iron deficiency defined by an additional presence of hypochromic microcytic anaemia.

Fifty-nine of $425(=14 \%)$ apparently healthy persons showed a latent iron deficiency. In the remaining 366 we established the following reference intervals for the concentration of transferrin in serum [ $\mu \mathrm{mol} / 1]$ : $25.2-45.3$ (males), 29.1-54.5 (females, $\leq 25$ years of age) and 25.3-48.6 (females, $>25$ years of age). Eight of 59 ( $=14 \%$ ) apparently healthy persons with latent iron deficiency had a transferrin concentration above the reference interval.

Sixty-one of $264(=23 \%)$ patients with an iron concentration $<7.2 \mu \mathrm{mol} / 1$ showed a ferritin concentration $<20 \mu \mathrm{g} / \mathrm{l}$ (males) and $<15 \mu \mathrm{g} / \mathrm{l}$ (females). Thirty-eight of these 61 patients $(=62 \%$ ) had a manifest iron deficiency. In 18 of these 38 patients $(=47 \%)$ the transferrin concentration was increased.

For our 264 patients we determined the diagnostic validity of an increased transferrin concentration for diagnosis of iron deficiency, assuming an iron deficiency if the concentration of ferritin remained below the discrimination values mentioned above: The diagnostic sensitivity was $36 \%$, the diagnostic specificity $97 \%$, the predictive value of the positive test result $79 \%$ and the predictive value of the negative test result $83 \%$.

It can be concluded that the diagnostic validity of transferrin determination is inferior to that of ferritin measurement with respect to the diagnosis of iron deficiency. This especially applies to diagnostic situations in which the prevalence of iron deficiency is far lower than in the present study: e. g., given a prevalence of iron deficiency anaemia of $0.81 \%$ as it can be observed in the general population the predictive value of the positive test result only amounts to $11.3 \%$.

Thus, determination of transferrin concentration does not yield further information, so that this test should no longer be used in the diagnosis of iron deficiency.

\section{Introduction}

Iron deficiency is the most common deficiency caused world-wide by faulty feeding. About $10-12 \%$ of all adults are characterized by a negative iron balance, in children the frequency is higher and in pregnant women the value is more than $50 \%$. Iron deficiency anaemia makes up more than $70 \%$ of all kinds of anaemia (1).
Iron deficiency is categorized as follows (for review see 1.c. (2)):

(a) Prelatent iron deficiency is characterized by an increased absorption of iron (e.g., in the course of the ${ }^{59} \mathrm{Fe}^{2+}$ whole-body retention test) as well as by a decreased amount of stored iron within the bone marrow. 
(b) Latent iron deficiency is defined by depleted iron stores: since the concentration of the iron storage protein ferritin in scrum is proportional to the amount of stored iron, a decreased concentration of ferritin in serum $(<20 \mu \mathrm{g} / \mathrm{l})$ [males] and $<15 \mu \mathrm{g} / \mathrm{l}$ [females]) is proof of depleted iron stores.

(c) Manifest iron deficiency exists if not only iron stores are depleted but also a decreased amount of haemoglobin-bound iron is present, resulting in hypochromic microcytic anaemia.

Transferrin, which transports iron in blood plasma, is a $\beta$-globulin with a relative molecular mass of about 79500. Each transferrin molecule is able to bind two $\mathrm{Fe}^{3+}$ ions (for review see 1.c. (3)).

Skikne et al. (4) found that in apparently healthy persons who had undergone repeated phlebotomies a decreased amount of stored iron is correlated with a rise in the transferrin concentration. In patients with manifest iron deficiency as well values of transferrin exceeding the upper reference limit have been reported $(5,6,7)$.

There are no studies of large numbers of healthy persons and patients in which the diagnostic validity of an increased transferrin concentration in the diagnosis of iron deficiency has been quantitatively determined. We therefore re-examined the efficacy of transferrin determination with respect to this question.

\section{Materials and Methods}

Apparently healthy persons and patients

We studied sera as well as venous whole blood specimens from

(a) 425 apparently healthy persons. The range of the age was 19 to 59 years (males) and 18 to 65 years (females).

Table 1 gives further details concerning the distribution of age and sex;

(b) 264 patients whose iron concentration in serum was $<7.2$ $\mu \mathrm{mol} / \mathrm{l}$.

Venipuncture from fasting subjects took place between 8 and 9 a. m. As anticoagulant the dipotassium salt of ethylenediaminetetraacetic acid was used.

Tab. 1 Age and sex distribution in apparently healthy persons $(n=425)$.

\begin{tabular}{lcccc}
\hline & \multicolumn{2}{l}{ Age [years] } & & \\
\cline { 2 - 5 } & below 26 & 26 to 45 & 46 to 65 & Sum \\
\hline Males & 31 & 121 & 6 & 158 \\
Females & 152 & 96 & 19 & 267 \\
\hline Sum & 183 & 217 & 25 & 425 \\
\hline
\end{tabular}

\section{Reagents}

Reagents for determination of serum iron concentration (method employing bathophenanthroline disulphonate as complexing reagent without deproteinization) (E. Merck, Darmstadt; no. 3307).

Reagents for determination of serum iron concentration (method employing bathophenanthroline disulphonate as complexing reagent with deproteinization) (Boehringer Mannheim $\mathrm{GmbH}$, Mannheim; no. 124214).

$\mathrm{N}$-protein standard serum (Behringwerke AG, Marburg; no. OSAU, lot 067642).

$\mathrm{N}$-antiserum for human transferrin (Behringwerke AG, Marburg; no. OSAX, lot 153432).

Reagents for determination of ferritin in human sera (Hybritech $\mathrm{GmbH}$, Cologne; no. 4145 BE, lot E24 072 908).

\section{Control materials}

Precinorm U (Boehringer Mannheim GmbH, Mannheim; no. 171735, lot 160564).

N/T protein control serum (human) (Behringwerke AG, Marburg; no. OSKE 06/07, lot 065127).

Control material 'low' and 'high' for quality control of ferritin determination (Hybritech $\mathrm{GmbH}$, Cologne; no. $4145 \mathrm{BE}$, lot E24 072 908).

\section{Equipment}

Spectral line photometer 6118 (Eppendorf Gerätebau Netheler + Hinz GmbH, Hamburg).

Coulter Counter S Plus VI (Coulter Electronics, Krefeld).

Behring Nephelometer Analyzer (Behringwerke AG, Marburg).

Photon Era (Hybritech $\mathrm{GmbH}$, Cologne) for fully mechanized performing of enzyme immunoassays.

\section{Procedures}

The measurements of haematological quantities (concentration of haemoglobin in whole blood, mean corpuscular haemoglobin $[\mathrm{MCH}]$ and mean corpuscular volume [MCV]) were performed with the Coulter Counter S Plus VI.

The iron concentration in serum was determined with the help of the spectral line photometer 6118 by using a method not requiring deproteinization (see above under "Reagents"). Only if the absorbance of the sample blank exceeded 0.200 (as measured against doubly distilled water) was the concentration of iron determined by employing reagents including a prior deproteinization step (see above under "Reagents").

Determination of serum transferrin $\left(M_{\mathrm{r}}=\hat{79} 500\right.$ (3)) concentration was performed by nephelometric measurement of antigen-antibody complexes composed of transferrin and antiserum against transferrin employing a Behring Nephelometer Analyzer.

Serum ferritin was measured employing a sandwich-type immunoassay with monoclonal antibodies against two different epitopes of the ferritin molecule by using the analyzer Photon Era.

\section{Statistical analysis}

Comparison of two independent samples was performed with the U-test according to Wilcoxon, Mann \&. Whitney (two-tailed test) (8). 
Tab. 2 Quality control of determination of iron, transferrin and ferritin in serum.

\begin{tabular}{|c|c|c|c|c|c|c|c|}
\hline Analyte & Unit & Control material & $\begin{array}{l}\text { Assigned } \\
\text { value }\end{array}$ & $8_{2 !}^{\prime \prime}$ & $\mathrm{SD}^{\mathrm{a}}$ & $\begin{array}{l}\text { CV } \\
(\%)^{a}\end{array}$ & $\begin{array}{l}\text { Relative systematic } \\
\text { deviation from the } \\
\text { assigned value (\%) }\end{array}$ \\
\hline Iron & $\mu \mathrm{mol} / 1$ & Precinorm U & $\begin{array}{l}17.4^{b} \\
17.7^{c}\end{array}$ & $\begin{array}{l}17.9 \\
16.8\end{array}$ & $\begin{array}{l}0.45 \\
0.40\end{array}$ & $\begin{array}{l}2.51 \\
2.38\end{array}$ & $\begin{array}{l}+2.87 \\
-5.08\end{array}$ \\
\hline Transferrin & $\mu \mathrm{mol} / 1$ & $\begin{array}{l}\text { N/T protein control } \\
\text { serum (human) }\end{array}$ & 40.5 & 40.4 & 1.11 & 2.75 & -0.25 \\
\hline Ferritin & $\mu g / 1$ & $\begin{array}{l}\text { Low control } \\
\text { High control }\end{array}$ & $\begin{array}{l}21.9 \\
475\end{array}$ & $\begin{array}{r}22.8 \\
451.3\end{array}$ & $\begin{array}{r}0.89 \\
10.95\end{array}$ & $\begin{array}{l}3.90 \\
2.43\end{array}$ & $\begin{array}{l}+4.11 \\
-4.99\end{array}$ \\
\hline
\end{tabular}

a mean and standard deviation from 20 determinations on different days;

$\mathrm{SD}=$ standard deviation; $\mathrm{CV}=$ coefficient of variation.

Relative systematic deviation from the assigned value $=\left[\left(\bar{x}_{20}-\right.\right.$ assigned value $)$ /assigned value $] \times 100$.

b method without deproteinization

c method with deproteinization

\section{Results}

\section{Quality control quantities}

The data of between-day imprecision and inaccuracy for the determination of iron, transferrin and ferritin are shown in table 2 . It can be concluded that the methods used in this study were under control.

\section{Apparently healthy persons}

Three-hundred-sixty-six of $425(=86 \%)$ apparently healthy persons were characterized by a ferritin con= centration $\geq 20 \mu \mathrm{g} / \mathrm{l}$ (males) and $\geq 15 \mu \mathrm{g} / \mathrm{l}$ (females) (= group A). The reference intervals established for persons belonging to group $\mathrm{A}$ are listed in table 3 .

Tab. 3 Reference intervals for different analytes in 366 apparently healthy persons with a ferritin concentration $\geq 20 \mu \mathrm{g} / \mathrm{l}$ (males) and $\geq 15 \mu \mathrm{g} / 1$ (females).

\begin{tabular}{|c|c|c|c|}
\hline Analyte & Unit & Sex & $\begin{array}{l}2.5 \text { th }-95.7 \text { th } \\
\text { percentile }\end{array}$ \\
\hline Haemoglobin & $\mathrm{mmol} / \mathrm{l}$ & $\begin{array}{l}\delta \\
q\end{array}$ & $\begin{array}{l}8.6-10.7 \\
7.5-9.5\end{array}$ \\
\hline $\mathrm{MCH}$ & fmol & & $1.74-2.11$ \\
\hline $\mathrm{MCV}$ & $\mathrm{fl}$ & & $84 \quad-98$ \\
\hline Iron & $\mu \mathrm{mol} / \mathrm{l}$ & $\begin{array}{l}\hat{\delta} \\
q\end{array}$ & $\begin{array}{ll}8.4 & -32.8 \\
7.7 & -36.9\end{array}$ \\
\hline Transferrin & $\mu \mathrm{mol} / \mathrm{l}$ & $\begin{array}{l}\delta \\
q, \leq 25 \text { years } \\
q,>25 \text { years }\end{array}$ & $\begin{array}{ll}25.2 & -45.3 \\
29.1 & -54.5 \\
25.3 & -48.6\end{array}$ \\
\hline
\end{tabular}

In figures 1 and 2 the dependence of the transferrin concentration in serum upon age and sex in persons belonging to group $A$ is shown. The transferrin concentration was higher in females than in males $(p<0.0001)$; there was no dependence of transferrin values upon age in males $(p>0.1)$, whereas females with an age not more than 25 years showed higher concentrations of transferrin than those with an age above 25 years $(p<0.0001)$ (see fig. 1a and 1b).

Fifty-nine ( 7 males and 52 females) of the 425 apparently healthy persons $(=14 \%)$ had ferritin concentrations $<20 \mu \mathrm{g} / \mathrm{l}$ (males) and $<15 \mu \mathrm{g} / \mathrm{l}$ (females) (= group B). None of'these 59 persons showed a haemoglobin concentration below the reference intervals listed in table 3 . Only in one female did we find a decreased iron concentration of $7.0 \mu \mathrm{mol} / 1$.

Transferrin concentrations were higher in group $B$ than in group $A(p<0.0001)$. Eight of $59(=14 \%)$ apparently healthy persons belonging to group B ( 2 of 36 female persons [age $\leq 25$ years], 3 of 16 female persons [age $>25$ years] and 3 of 7 male persons) showed a transferrin concentration above the reference intervals listed in table 3.

Quantitative determination of the diagnostic validity of increased transferrin values with respect to the diagnosis of iron deficiency

Sixty-one of 264 patients examined ( $=23 \%$ ), who showed an iron concentration $<7.2 \mu \mathrm{mol} / \mathrm{l}$, had a decreased ferritin concentration (i. e., $<20 \mu \mathrm{g} / \mathrm{l}$ [males] and $<15 \mu \mathrm{g} / \mathrm{l}$ [females]).

We examined whether transferrin determination is suitable for prediction of a decreased ferritin concentration (i. e., $<20 \mu \mathrm{g} / \mathrm{l}$ [males] and $<15 \mu \mathrm{g} / \mathrm{l}$ [females]). For this purpose we defined a transferrin concentration above the reference intervals listed in table 3 as a positive test result, a transferrin concentration equal to or 


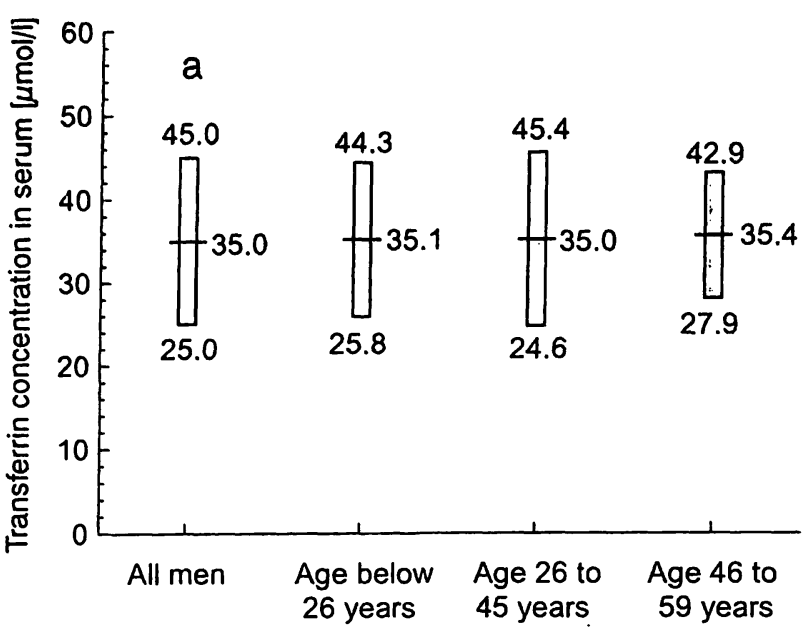

b

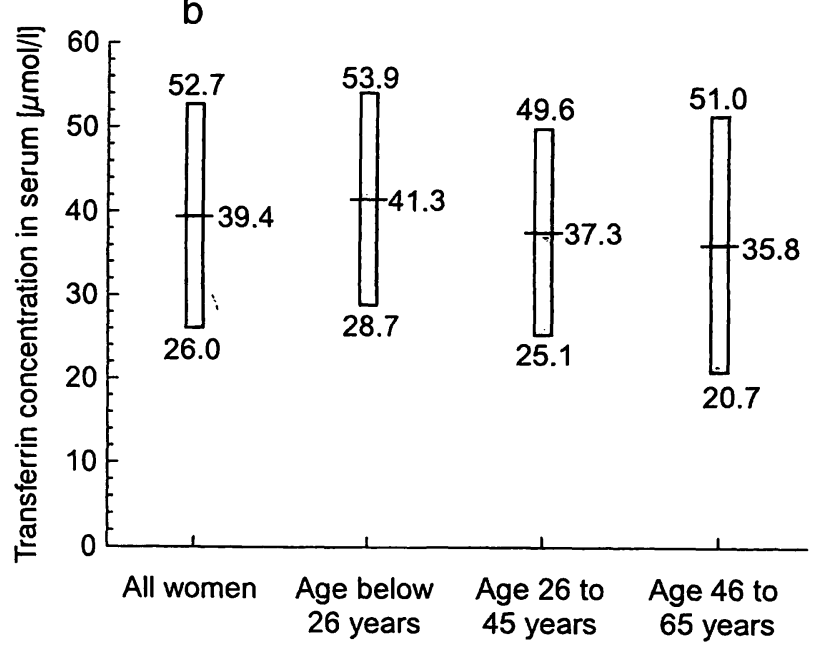

Fig. 1 Dependence of transferrin concentration in serum upon age and sex in 366 apparently healthy persons showing a ferritin concentration $\geq 20 \mu \mathrm{g} / \mathrm{l}$ (males) and $\geq 15 \mu \mathrm{g} / \mathrm{l}$ (females)

The persons were divided into the following subgroups:

Fig. 1a) All men $(n=151)$; (Ia) men (below 26 years) $(n=28)$; $(\mathrm{Ib})$ men $(26$ to 45 years) $(\mathrm{n}=117)$; (Ic) men ( 46 to 59 years)
$(\mathrm{n}=6)$.

Fig. 1b) All women ( $\mathrm{n}=215)$; (IIa) women (below 26 years) $(\mathrm{n}=116)$; (Ilb) women (26 to 45 years) $(\mathrm{n}=81)$; (IIc) women (46 to 65 years $)(n=18)$.

The mean as well as mean $\pm 2 \times$ standard deviations are shown. In the following subgroups we examined whether the distributions of transferrin concentration differed from each other:

(I) compared with (II): $p<0.0001$

(Ia) compared with (Ib): $\mathrm{p}>0.1$

(la) compared with (Ic): $\mathrm{p}>0.1$

(lb) compared with (lc): $\mathrm{p}>0.1$

(IIa) compared with (IIb): $\mathrm{p}<0.0001$

(Ila) compared with (IIc): $\mathrm{p}<0.01$

(Ilb) compared with (IIc): $\mathrm{p}>0.1$

lower than the reference interval as a negative test result. The probability of a positive test result in patients with a decreased ferritin concentration (= diagnostic sensitivity) was $22 / 61(=36 \%)$; the probability of a negative test result in patients without a decreased ferritin concentration (= diagnostic specificity) was 197/203 $(=97 \%)$; the probability of a decreased ferritin concentration in patients with a positive test result $(=$ pre- dictive value of a positive test result) was $22 / 28$ (= $79 \%$ ); and the probability of a ferritin concentration not being decreased in patients with a negative test result (= predictive value of a negative test result) was 197/ $236(=82 \%)$.

\section{Patients with depleted iron stores - comparison between different subgroups}

Those 61 patients who showed a ferritin concentration $<20 \mu \mathrm{g} / \mathrm{l}$ (males) and $<15 \mu \mathrm{g} / \mathrm{l}$ (females) were divided into 4 subgroups, whose characteristics are listed in table 4 .

The 38 patients of group 1 (= patients with hypochromic microcytic anaemia) on the average showed higher transferrin concentrations than those apparently healthy persons belonging to group A $(p<0.0001)$. Of these 38 patients $18(=47 \%$ ) ( 1 of 6 female persons [ $\leq 25$ years of age], 9 of 19 female persons [ $>25$ years of age] and 8 of 13 male persons) showed a transferrin concentration above the reference intervals listed in table 3. Figure 2 shows the frequency distribution of transferrin concentration in patients with hypochromic microcytic anaemia and in apparently healthy persons belonging to group A. For the analytes iron, ferritin and haemoglobin (as independent variables) and transferrin (as dependent variable) we calculated correlation coefficients as given in table 5 .

The clinical diagnoses established in those patients belonging to groups 2 and 3 (see tab. 4) are shown in table 6. The range of $\mathrm{MCH}$ in patients of group 2 (= patients with hypochromic normocytic anaemia) was $1.49-1.74$ fmol and that of MCV was 83-89 fl. Of the 23 patients belonging to groups 2, 3 and 4, 4 (=17\%) ( 2 of 7 from group 2, 1 of 7 from group 3 and 1 of 9 from group 4) showed a transferrin concentration above the reference intervals listed in table 3. The clinical diagnoses of those patients belonging to groups 2,3 and 4, showing an increased transferrin concentration were alcoholism with dietary iron deficiency (group 2), Crohn's disease (group 2), anaemia of chronic renal failure (group 3) and chronic blood loss from an oesophageal ulcer (group 4). The 16th and 84th percentile, as well as the median of the transferrin values, in persons belonging to groups 1 , 2, 3 and 4 compared with those 203 patients (= group $0)$ who had a ferritin concentration $\geqslant 20 \mu \mathrm{g} / \mathrm{l}$ (males) and $\geqslant 15 \mu \mathrm{g} / 1$ (females) are shown in figure 3 .

\section{Discussion}

A higher transferrin concentration in healthy women compared with healthy men, as well as a dependence of transferrin values upon age, has not hitherto been de- 
Tab. 4 Classification of 61 patients with an iron concentration $<7.2 \mu \mathrm{mol} / 1$ as well as a ferritin concentration $<20 \mu \mathrm{g} / \mathrm{l}$ (males) and $<15 \mu \mathrm{g} / \mathrm{l}$ (femalcs).

\begin{tabular}{|c|c|c|}
\hline Sample & Characteristics & \\
\hline \multicolumn{3}{|l|}{ Group 1: } \\
\hline $\begin{array}{l}\text { Patients with depleted iron stores and } \\
\text { hypochromic microcytic anacmia }(n=38)\end{array}$ & $\begin{array}{l}\text { Haemoglobin } \\
\mathrm{MCH} \\
\mathrm{MCV}\end{array}$ & $\begin{array}{l}<8.7 \mathrm{mmol} / 1 \text { (males) } \\
<7.4 \mathrm{mmol} / 1 \text { (females) } \\
<1.74 \mathrm{fmol} \\
<83 \quad \mathrm{fl}\end{array}$ \\
\hline \multicolumn{3}{|l|}{ Group 2: } \\
\hline $\begin{array}{l}\text { Patients with depleted iron stores and } \\
\text { hypochromic normocytic anaemia }(n=7)\end{array}$ & $\begin{array}{l}\text { Haemoglobin } \\
\mathrm{MCH} \\
\mathrm{MCV}\end{array}$ & $\begin{array}{l}<8.7 \mathrm{mmol} / 1 \text { (males) } \\
<7.4 \mathrm{mmol} / 1 \text { (females) } \\
<1.74 \mathrm{fmol} \\
\geq 83 \quad \mathrm{fl}\end{array}$ \\
\hline \multicolumn{3}{|l|}{ Group 3: } \\
\hline $\begin{array}{l}\text { Patients with depleted iron stores and } \\
\text { normochromic normocytic anaemia }(n=7)\end{array}$ & $\begin{array}{l}\text { Haemoglobin } \\
\mathrm{MCH} \\
\mathrm{MCV}\end{array}$ & $\begin{array}{l}<8.7 \mathrm{mmol} / 1 \text { (males) } \\
<7.4 \mathrm{mmol} / 1 \text { (females) } \\
\geq 1.74 \mathrm{fmol} \\
\geq 83 \quad \mathrm{fl}\end{array}$ \\
\hline \multicolumn{3}{|l|}{ Group 4: } \\
\hline $\begin{array}{l}\text { Patients with depleted iron stores without } \\
\text { anacmia }(n=9)\end{array}$ & Haemoglobin & $\begin{array}{ll}\geq 8.7 \mathrm{mmol} / \mathrm{l} \text { (males) } \\
\geq 7.4 \mathrm{mmol} / \mathrm{l} \text { (females) }\end{array}$ \\
\hline
\end{tabular}

scribed. In 773 male and 680 female persons (mainly blood-donors) Dati et al. (9) did not find a significant dependence of transferrin values upon sex, although the same method for transferrin determination was employed as in this paper. The reference interval described by Dati et al. (9) $(28.9-54.1 \mu \mathrm{mol} / \mathrm{l})$ - defined as 2.5 th to 97.5 th percentile - essentially corresponds to that established by us for women with an age not more than 25 years. In the present study, however, only persons were used as reference individuals who did not show a latent iron deficiency (concentration of ferritin $<20 \mu \mathrm{g} / \mathrm{l}$ [males] and $<15 \mu \mathrm{g} / 1$ [females]). The prevalence of latent iron deficiency amounts to $60 \%$ in male blood-do-

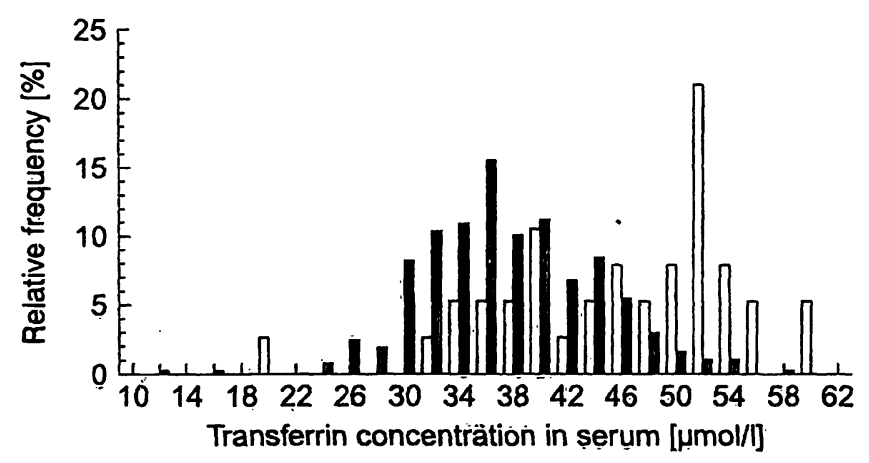

Fig. 2 Distribution of transferrin concentration in apparently healthy persons with a ferritin concentration $\geq 20 \mu \mathrm{g} / \mathrm{l}$ (males) and $\geq 15 \mu \mathrm{g} / \mathrm{l}$ (females) $(\mathrm{n}=366)$, as well as in patients with a hypochromic microcytic iron deficiency anaemia $(n=38)$.

Black bars: apparently bealthy persons. White bars: patients with iron deficiency anaemia. nors and $75 \%$ in female blood-donors (10). Therefore, it cannot be excluded that in blood-donors a latent iron deficiency results in higher transferrin values, masking the dependence of transferrin values upon age and sex observed by us. The upper reference limits as reported by other research groups lie between 39.0 and 54.1 $\mu \mathrm{mol} / 1(6,7,9,11,12,13)$. Presumably, the different reference limits can be explained by an insufficient characterization of the reference population with respect to age, sex and presence of an iron deficiency (see above), as well as by the use of reagents and standards of dissimilar composition, the different numbers of reference individuals examined and different statistical evaluations (calculation of mean $\pm 2 \times$ standard deviation and 2.5 th -97.5 th percentile).

In apparently healthy persons who did not show any signs of iron deficiency (as proved by haemoglobin concentrations $>8.1 \mathrm{mmol} / \mathrm{l}$ [males] and $>7.4 \mathrm{mmol} / 1$ [females] as well as by a transferrin saturation $>20 \%$ )

Tab. 5 Correlation coefficients for the analytes iron, ferritin and haemoglobin (as independent variables) and transferrin (as dependent variable) in 38 patients with hypochromic microcytic iron deficiency anaemia.

\begin{tabular}{llll}
\hline & $\begin{array}{l}\text { Iron in } \\
\text { serum }\end{array}$ & $\begin{array}{l}\text { Ferritin in } \\
\text { serum }\end{array}$ & $\begin{array}{l}\text { Haemoglobin in } \\
\text { whole blood }\end{array}$ \\
\hline $\mathrm{r}$ & -0.146 & -0.424 & -0.249 \\
$\mathrm{p}$ & $>0.1$ & $<0.01$ & $>0.1$ \\
\hline
\end{tabular}


Tab. 6 Clinical diagnoses of paticnts with depleted iron stores and (a) hypochromic normocytic anacmia or (b) normochromic normocytic annemia (= groups 2 and 3 ; sec table 4).

Group 2 (hypochromic normocytic anacmia; $\mathbf{n}=7$ )

Crohn's discase (3)

Ulccrative colitis (1)

Alcoholism with dietary iron deficiency (1)

Alcoholic liver cirrhosis with chronic blood loss from oesophageal varices (1)

Mesangioproliferative glomerulonephritis with urinary loss of transferrin (I)

Group 3 (normochromic normocytic anaemia; $\mathrm{n}=7$ )

Crohn's disease (1)

Osler's disease with acutc blood loss (1)

Poisoning with coumarin derivatives leading to acute blood loss (1)

Chronic myelogenous leukaemia (1)

Traumatic cardiac haemolytic anaemia and chronic blood loss from a gastric ulcer (1)

Anaemia of chronic renal failure (2)

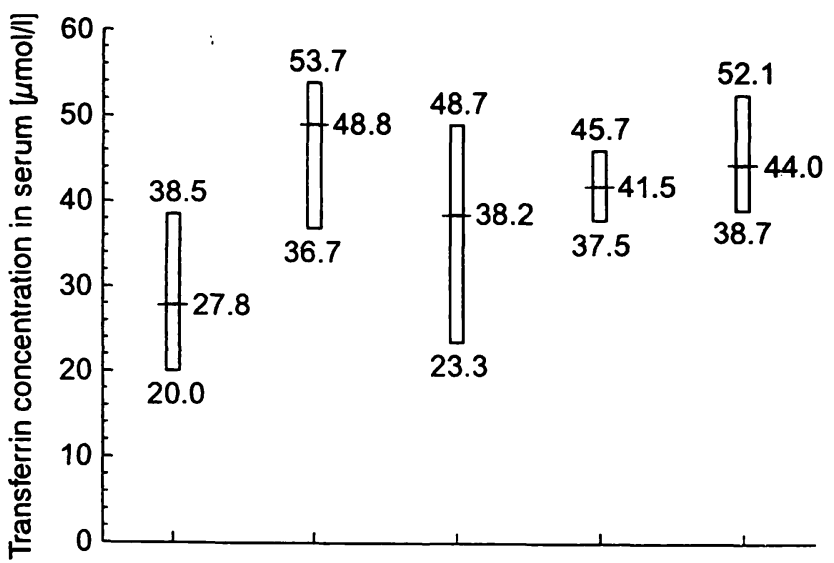

Group 0 Group 1 Group 2 Group 3 Group 4

Fig. 3 Comparison of transferrin concentration in different subgroups of 61 patients with a ferritin concentration $<20 \mu \mathrm{g} / \mathrm{l}$ (males) and $<15 \mu \mathrm{g} / \mathrm{l}$ (females).

See table 4 for the characteristics of groups 1, 2,3 and 4 . In group 0 there are all 203 patients characterized by a ferritin concentration $\geq 20 \mu \mathrm{g} / \mathrm{l}$ (males) and $\geq 15 \mu \mathrm{g} / \mathrm{l}$ (females). The 16th and the 84th percentile (lower and upper end of the bars) are shown, as well as the median.

In the following groups we examined whether the frequency distributions of transferrin concentration differed from each other:

' 0 ' compared with ' 1 ': $p<0.0001$

' 0 ' compared with ' 2 ': $\mathrm{p}<0.05$

' 0 ' compared with ' 3 ': $\mathrm{p}<0.0001$

' 0 ' compared with ' 4 ': $\mathrm{p}<0.0001$

' 1 ' compared with ' 2 ': $p<0.05$

' 1 ' compared with ' 3 ': $p<0.1$

' 1 ' compared with ' 4 ': $p>0.1$

' 2 ' compared with ' 3 ': $\mathrm{p}>0.1$

' 2 ' compared with ' 4 ': $p>0.1$

' 3 ' compared with ' 4 ': $\mathrm{p}>0.1$

transferrin and ferritin concentrations are negatively correlated $(r=-0.28$ for females and -0.27 for males (14)). The latent iron deficiency used to characterize the apparently healthy persons belonging to group $\mathrm{B}$, did result in significantly higher transferrin values (as compared with persons of group A), but the diagnostic sensitivity of an increased transferrin concentration with regard to diagnosing depleted iron stores (14\%) is too low to be diagnostically relevant. Schmidt \& Gulich (10) as well found transferrin values abovie' $50.3 \mu \mathrm{mol} / \mathrm{l}$ in only $30 \%$ of male blood-donors with a ferritin concentration $<30 \mu \mathrm{g} / \mathrm{l}$ and in $13 \%$ of female blood-donors with a ferritin concentration $<20 \mu \mathrm{g} / \mathrm{l}$. Also in children characterized by a latent iron deficiency (ferritin concentration $<11 \mu \mathrm{g} / \mathrm{l}$ ) the transferrin values were not significantly higher than those of a reference collective (15).

The hitherto reported values of the diagnostic sensitivity of an increased transferrin concentration with respect to diagnosing a manifest iron deficiency are contradictory: Tsung et al. (7) found increased transferrin values in 11 of 16 patients with a manifest iron deficiency, Rajamäki et al. (6), however, in merely 5 of 51 cases. The value of the diagnostic sensitivity of an increased transferrin concentration established by us in patients with a hypochromic microcytic anaemia (47\%) essentially corresponds to that reported by Bainton \& Finch (5) who found values for the total iron-binding capacity above $64.5 \mu \mathrm{mol} / 1$ (upper reference limit) in more than $50 \%$ of patients with a manifest iron deficiency.

Thus the diagnostic sensitivity of an increased transferrin concentration with respect to diagnosing a manifest iron deficiency is higher than that for a latent one; it is, however, too low to be diagnostically relevant. A possible cause of this low diagnostic sensitivity might be the fact that the transferrin concentration is also dependent both upon the synthetic capacity of the liver as well as upon the protein intake (16).

The fact must be stressed, however, that the diagnostic validity of an increased transferrin concentration with respect to a latent or manifest iron deficiency depends upon the prevalence of iron deficiency in the collective examined. In the present study the probability of a decreased ferritin concentration in patients with an increased transferrin value is $79 \%$, with the prevalence of. iron deficiency being $23 \%$. In a group of 253 children (not suffering from anaemia) with a $9 \%$ ferritin concentration $<10 \mu \mathrm{g} / \mathrm{l}$, Milman \& Cohn (13), however, found that only in $27 \%$ of those children who were characterized by an increased transferrin value $(>43 \mu \mathrm{mol} / \mathrm{l})$ was the ferritin concentration $<10 \mu \mathrm{g} / 1$.

For the interpretation of the data with respect to predictive value the fact has to be taken into account that the patient sample examined by us does not correspond to the general population. The patients are pre-selected be- 
cause of the diseases that led to their admission to the hospital. The influence of the prevalence of iron deficiency anaemia on the predictive values is shown in table 7.

It can be concluded that the diagnostic sensitivity of an increased transferrin value is inferior to that of a ferritin determination, so that in the diagnosis of iron deficiency one can dispense with transferrin determination, especially since nowadays the concentration of ferritin can be measured in non-specialized laboratories. This also applies to the determination of total iron-binding capacity (1).

\section{Acknowledgements}

We thank Mrs. S. Förster and Miss H. Irmer for skilful technical assistance.

\section{References}

1. Braun, B.-E., Goes, R., Krieg, M. \& Trampisch, H. J. (1989) Zur Entbehrlichkeit der konventionell bestimmten totalen Eisenbindungskapazität (TEBK) im Rahmen der EisenmangelDiagnostik. Lab. Med. 13, 491-497.

2. Schröcksnadel, W. \& Gabl, F. (1984) Die Diagnostik des gestörten Eisenstoffwechsels. Wien. Med. Wochenschr. 134, 63-68.

3. Huebers, H. A. \& Finch, C. A. (1984) Transferrin: Physiological behavior and clinical implications. Blood 64, 763-767.

4. Skikne, B. S., Flowers, C. H. \& Cook, J. D. (1990) Serum transferrin receptor: A quantitative measure of tissue iron deficiency. Blood 75, 1870-1876.

5. Bainton, D. F. \& Finch, C. A. (1964) The diagnosis of iron deficiency anemia. Am. J. Med. 37, 62-70.

6. Rajamäki, A., Irjala, K. \& Aitio, A. (1979) Immunochemical determination of serum transferrin - reference values, correlation with total iron-binding capacity and value in the diagnosis of iron deficiency anaemia and anaemia of chronic disorders. Scand. J. Haematol. 23, 227-231.

7. Tsung, S. H., Rosenthal, W. A. \& Milewski, K. A. (1975) Immunochemical measurement of transferrin compared with chemical measurement of total iron-binding capacity. Clin. Chem. 21, 1063-1066.

8. Sachs, L. (1988) Statistische Methoden. Plamung und Auswertung. 6., neubearb. und erw. Aufl., Springer, Berlin Heidelberg New York London Paris Tokyo.

9. Dati, F., Lammers, M., Adam, A., Sondag, D. \& Stienen, L. (1989) Referenzwerte für 18 Plasmaproteine am BehringNephelometer-System. Lab. Med. 13, 87-90.
Tab. 7 Influence of the prevalence of iron deficiency anaemia upon the predictive value of an increase or no increase in transferrin concentration in serum.

\begin{tabular}{llll}
\hline & \multicolumn{3}{l}{ Prevalence $^{\mathrm{a}}$} \\
\cline { 2 - 4 } & $0.81 \%$ & $12.6 \%$ & $14.4 \%$ \\
\hline $\begin{array}{c}\text { Predictive value of a } \\
\text { positive test result }\end{array}$ & $11.3 \%$ & $69.3 \%$ & $72.5 \%$ \\
$\begin{array}{c}\text { Predictive value of a } \\
\text { negative test result }\end{array}$ & $99.6 \%$ & $92.7 \%$ & $91.6 \%$ \\
\hline
\end{tabular}

a Prevalence of iron deficiency anaemia in adult men $(0.81 \%)$ and in adult women (12.6\%) (17) as well as prevalence of iron deficiency anaemia in 264 patients examined in the present study (14.4\%).

b Probability of iron deficiency anaemia in persons with increased transferrin values.

c Probability of iron deficiency anaemia being absent in persons with transferrin values not being increased.

The predictive values are calculated by assuming:

(1) The diagnostic sensitivity of a transferrin concentration above the reference interval with respect to the diagnosis of iron deficiency anaemia is $47 \%$.

(2) The diagnostic specificity is $97 \%$.

10. Schmidt, L. H. \& Gulich, W. (1990) Sind unsere Blutspender durch den Eisenmangel gefährdet? Folia Haematol. 117, 457-460.

11. Kreutzer, H. J. H. (1976) An immunological turbidimetric method for serum transferrin determination. J. Clin. Chem. Clin. Biochem. 14, 401-406.

12. Markowitz, H. \& Fairbanks, V. F. (1983) Transferrin assay and total iron binding capacity. Mayo Clin. Proc. 58, 827-828.

13. Milman, N. \& Cohn, J. (1984) Serum iron, serum transferrin and transferrin saturation in healthy children without iron deficiency. Eur. J. Pediatr. 143, 96-98.

14. Cook, J. D., Lipschitz, D. A., Miles, L. E. M. \& Finch, C. A. (1974) Serum ferritin as a measure of iron stores in normal subjects. Am. J. Clin. Nutr. 27, 681-687.

15. Bender-Götze, C., Pilar, v. C. E. \& Fischer, N. (1980) Vergleichende Bestimmung von indirekt (totale Eisenbindungskapazität) und direkt gemessenem Transferrin bei gesunden und kranken Kindern. Monatsschr. Kinderheilk. 128, 598-601.

16. Quirin, H., Jutzler, G. A., Traut, R., Baumann, G., Bischof, G. \& Kluthe, R. (1973) Serumtransferrin bei chronisch hämodialysierten Patienten unter kontrollierter diätetischer Eiweißzulage. Klin. Wochenschr. 51, 247-248.

17. Wintrobe, M. M., Lee, G. R., Boggs, D. R., Bithell, T. C., Athens, J. W. \& Foerster, J. (1974) Clinical Hematolog: 7th edn., pp. 635-670, Lea \& Febiger, Philadelphia.

Dr. med. Wolfgang Withold Institut für Klinische Chemie und Laboratoriumsdiagnostik Heinrich-Heine-Universität Moorenstraße 5 D-40225 Düsseldorf Germany 
